\title{
Оцінка функціонального ниркового резерву після резекціі нирки у хворих з нирково-клітинним раком різних вікових груп
}

\author{
С. М. Пасічник \\ Львівський національний медичний університет імені Данила Галицького
}

\section{Estimation of functional renal reserve after renal resection in patients with reno-cellular cancer in the groups of various age}

\author{
S. M. Pasichnyk
}

Danylo Galytskyi Lviv National Medical University

\section{Реферат}

Мета. Оцінити функціональний нирковий резерв (ФНР) у хворих на ранніх стадіях нирково-клітинного раку (НКР) різних вікових груп та його зміни в післяопераційному періоді.

Матеріали і методи. У дослідженні взяли участь 49 хворих з НКР на стадії T1NOMO, $\mathrm{G}_{1}$ - $\mathrm{G}_{3}$, гістологічний підтип НКР світлоклітинний рак. У всіх хворих спостерігали ознаки сечового синдрому. Всім хворим виконали резекцію нирки. У 1 -шу групу включили 9 пацієнтів віком 25 - 43 роки, середній вік становив $(34 \pm 2,3)$ року; у 2 -гу групу - 17 пацієнтів віком 44-59 років, середній вік становив $(50 \pm 1,3)$ року; у 3 -тю групу - 23 хворих віком 60 - 74 роки, середній вік становив $(67 \pm 2,1)$ року. Швидкість клубочкової фільтрації у всіх хворих дорівнювала або перевищувала 90 мл/хв $/ 1,73$ м². Результати. Через 1 міс після проведеного хірургічного лікування середне значення ФНР у пацієнтів 1-ї групи становило $(13,60 \pm 1,24) \%, 2-і ̈$ групи - $(8,70 \pm 0,21) \%$. Через 12 міс після проведеного хірургічного лікування середнє значення ФНР у хворих $3-і ̈$ групи становило $(3,22 \pm 1,16) \%$.

Висновки. У пацієнтів з НКР віком від 25 до 43 років ФНР збережений. Резекція нирки у пацієнтів даної вікової групи не призводить до зниження ФНР протягом 12 міс спостереження. У пацієнтів з НКР віком від 44 до 59 років ФНР також збережений. Після резекції нирки у пацієнтів даної вікової групи протягом 12 міс спостереження відбувається зниження ФНР. У пацієнтів з НКР віком від 60 до 75 років ФНР знижений. Після резекції нирки пацієнти даної вікової групи протягом 12 міс спостереження втрачають ФНР.

Ключові слова: рак нирки; функціональний нирковий резерв; нирково-клітинний рак; нефректомія; резекція нирки; радикальна нефректомія.

Abstract

Objective. To estimate a functional renal reserve (FRR) in patients on early stages of reno-cellular cancer (RCC) in various age groups and its changes in postoperative period.

Materials and methods. In the investigation 49 patients, suffering RCC Stages T1NOMO, $G_{1}-G_{3}$, histological subtype of RCC - clear-cellular cancer, took part. In all the patients the signs of urinal syndrome were revealed and renal resection accomplished. Into the Group I 9 patients were included, ageing $25-43$ yrs old, the average age have constituted (34 \pm 2.3$)$ yrs; and into the Group II - 17 patients, ageing 44-59 yrs old, the average age have constituted ( $50 \pm 1.3$ ) yrs old; into the Group III -23 patients, ageing $60-74$ yrs old, average age have constituted $(67 \pm 2.1)$ yrs. The glomerular filtration rate in all the patients have equaled or exceeded $90 \mathrm{ml} / \mathrm{min} / 1.73 \mathrm{~m}^{2}$.

Results. In $1 \mathrm{mo}$ after conduction of surgical treatment an average value of FRR in patients of the Group I have constituted $(13.60 \pm 1.24) \%$, while in the Group II $-(8.70 \pm 0.21) \%$. In 12 mo after conduction of surgical treatment the average value of FRR have constituted $(3.22 \pm 1.16) \%$.

Conclusion. In the patients, suffering RCC and ageing $25-43$ yrs old, FRR was preserved. Renal resection in patients of this age group do not lead to lowering of FRR during 12 mo of observation. In the patients, suffering RCC and ageing $44-59$ yrs old FRR is preserved also. After renal resection in patients of this age group during 12 mo of observation the FRR lowering occurs. In the patients, suffering RCC and ageing $60-75$ yrs old FRR is lowered. After renal resection the patients of this age group during 12 mo losses FRR.

Keywords: renal cancer; functional renal reserve; reno-cellular cancer; nephrectomy; renal resection; radical nephrectomy.

В останні роки значно зросла частота виявлення раку нирки (РН). Щорічно у світі діагностують близько 338 тис. нових хворих із даною патологією, а приріст захворюваності становить 2 - 4\%. В Україні щорічно діагностують РН у майже 5 тис. пацієнтів віком від 35 до 70 років. Найвища захворюваність на РН характерна для осіб віком 60 - 70 років, причому у чоловіків РН виявляють у півтора разу часті- ше, ніж у жінок. Кожного року помирають близько 2 тис. хворих із даною патологією. У 2006 р. було 4598 хворих 3 РН, померли 2300. Захворюваність на РН у 2005 р. становила 10,3 (грубий показник), 6,8 (світовий стандарт), 9,8 (український стандарт 2000 р.) спостереження на 100 тис. населення - відповідно 13,3; 9,8; 14,6 спостереження на 100 тис. чоловіків і 7,8; 4,8; 6,8 спостереження на 100 тис. жінок [1 - 4]. 
Близько 90\% первинних пухлин нирок є злоякісними, із них 80 - 85\% припадає на нирково-клітинний рак (НКР).

До етіологічних чинників насамперед слід віднести куріння, надмірну масу тіла, артеріальну гіпертензію.

У більш як 50\% хворих НКР є випадковою знахідкою. На початкових стадіях клінічні прояви захворювання, як правило, досить незначні або їх узагалі може не бути. Характерні клінічні прояви РН у більшості пацієнтів спостерігають на більш глибоких стадіях захворювання.

Основними методами лікування НКР є: хірургічне видалення пухлини (нефректомія, резекція нирки), хіміотерапія, променева терапія (чутливість пухлини нирки до опромінення $€$ невисокою, проте у пацієнтів з метастазами та вираженим больовим синдромом ії застосовують 3 паліативною метою), імунотерапія, таргетна терапія, передопераційна та паліативна емболізація.

«Золотий стандарт» у лікуванні $\mathrm{PH}$ - застосування хірургічного методу. Резекція нирки на сьогодні стала бажаною альтернативою радикальній нефректомії у пацієнтів з пухлинами стадії Т1. Органозберігаючі операції порівняно з радикальною нефректомією мають рівноцінний онкологічний результат при пухлинах діаметром менше 4 см [5 - 9]. Хірургічне лікування РН у ряді спостережень може викликати або прискорювати розвиток уже існуючої ниркової недостатності [10]. Окрім того, відомо, що з віком, коли відбувається старіння організму, функціональні можливості органів сечовидільної системи знижуються: у людей похилого віку кількість нефронів у середньому зменшується на третину, а то й на половину, а фільтраційна площа ниркових клубочків 3 1,5 до 0,9 м² [11, 12].

У результаті проведених досліджень вчені оцінили, як старіння впливає на ключові клітинні процеси, якими є аутофагія, функціонування мітохондрій та окисний стрес. Також було запропоновано перспективні методи лікування ниркової недостатності.

Наприкінці 80-х років уперше звернули увагу на те, що клубочкова фільтрація в умовах функціонального спокою, а також у разі виконання різних навантажень і зміни гомеостатичних функцій нирками може істотно коливатися $[13,14]$. Причому стало зрозуміло, що в більшості спостережень виконання тих чи інших видів роботи нирок супроводжується збільшенням клубочкової фільтраціï. У результаті було сформоване уявлення про те, що в умовах відносного спокою нирки клубочкова фільтрація перебуває на фізіологічному мінімально низькому рівні, тоді як виконання додаткових функцій, включення в дію ряду адаптивних реакцій супроводжується збільшенням клубочкової фільтрації. Відтак різницю між показниками клубочкової фільтрації в умовах спокою організму і під час виконання додаткової роботи назвали функціональним нирковим резервом (ФНР) [15 - 19].

Функція нирок, подібно функції інших органів, є динамічною і постійно пристосовується до змін у внутрішньому середовищі для підтримки гомеостазу. Швидкість клубочкової фільтрації (ШКФ) служить основним показником функції нирок у клінічній практиці. За даними про
ФНР можна додатково судити про здоров'я нирок і в перспективі прогнозувати стан функції нирок у віддаленому після проведеного лікування періоді.

Незважаючи на давній інтерес до ФНР як біомаркера в нефрології, його основні механізми залишаються недостатньо зрозумілими. Більше того, не досягнуто консенсусу щодо його кількісного визначення. У попередніх дослідженнях використовували різні методи вимірювання ФНР і отримували результати, що різнилися. Стандартизований і клінічно доцільний підхід до кількісного визначення ФНР дасть змогу більш ретельно оцінити його цінність як біомаркера і прокласти шлях до завпровадження «клінічних стрес-тестів» у клінічну практику [20].

Мета дослідження: вивчення ФНР у хворих з ранніми стадіями НКР різних вікових груп, змін даного показника в післяопераційному періоді, що нині є надзвичайно актуальним і до кінця не вивченим.

\section{Матеріали і методи дослідження}

У дослідженні взяли участь 49 хворих з НКР. У всіх хворих НКР діагностовано вперше, стадія T1NOM0 відповідно до Міжнародної класифікації ТNM. Гістологічна градація за Фурманом: $G_{1}-G_{3}$, гістологічний підтип НКР: світлоклітинний рак. У всіх пацієнтів спостерігали ознаки сечового синдрому. 3 лікувальною метою всім хворим було виконано хірургічне втручання - резекцію нирки. Відповідно до вікових періодів згідно з визначенням ВООЗ усіх пацієнтів розподілили на три групи: 1 -шу - 9 (18,37\%) пацієнтів віком 25 - 43 роки, середній вік становив $(34 \pm 2,3)$ року; 2-гу -17 (34,69\%) пацієнтів віком $44-59$ роки, середній вік становив (50 $\pm 1,3)$ року; 3-тю - 23 (46,94\%) пацієнти віком 60 - 74 роки, середній вік становив $(67 \pm 2,1)$ року. ШКФ у всіх хворих дорівнювала або перевищувала 90 мл/хв/1,73 м². Усі пацієнти, які взяли участь у дослідженні, не мали будь-яких додаткових факторів ризику, що могли б впливати на анатомо-функціональний стан нирок, зокрема артеріальної гіпертензіі, цукрового діабету тощо. Дані опрацьовували статистично з використанням прикладних статистичних методів за допомогою програмного пакета Microsoft Excel 2016.

\section{Результати}

Результати дослідження щодо динаміки змін ФНР у всіх пацієнтів з НКР оцінювали під час первинного огляду та через 1 міс від початку проведення лікувально-діагностичних заходів.

До проведення хірургічного лікування середне значення ФНР у пацієнтів $1-і ̈$ групи становило $(15,12 \pm 0,31) \%$, у пацієнтів 2-ї групи - $(13,70 \pm 0,11) \%$, у пацієнтів 3-ї групи $-(7,18 \pm 0,25) \%$.

Через 1 міс після проведеного хірургічного лікування середнє значення ФНР у пацієнтів 1-ї групи становило $(13,60 \pm 1,24) \%(p>0,05)$, у пацієнтів 2-ї групи - $(8,70$ $\pm 0,21) \%(p<0,05)$, у пацієнтів 3-ї групи - $(3,22 \pm 1,16) \%$ ( $>$ > 0,05). Через 1 міс після проведеного хірургічного лікування виявлено статистично достовірну різницю змі- 


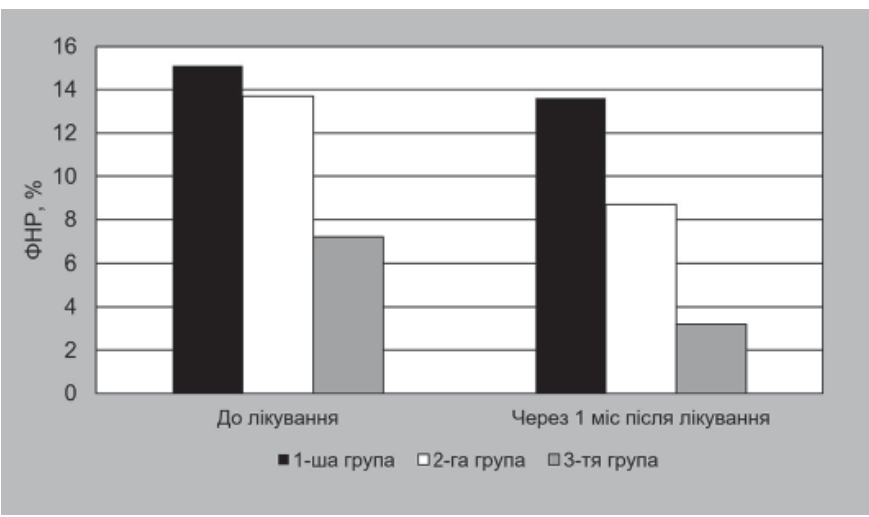

Розподіл груп хворих за величиною ФНР під час первинного огляду та через 1 міс після проведення хірургічного лікування.

ни ФНР у пацієнтів 1-ї та 3-ї груп і у пацієнтів 2-ї та 3-ї груп, а різниця зміни ФНР у пацієнтів 1-ї та 2-ї груп була статистично недостовірною (див. рисунок).

Моніторинг механізмів втрати нирками функціонуючої тканини шляхом вивчення величини ФНР одночасно з проведенням діагностичних заходів, скерованих на визначення порушення основних ниркових функцій у хворих різних вікових груп, яким було проведено хірургічне лікування з приводу НКР, дасть змогу індивідуально прогнозувати перебіг хронічної хвороби нирок, запобігаючи настанню незворотних процесів та формуючи адекватний терапевтичний підхід у кожному конкретному спостереженні.

\section{Обговорення}

Приріст ШКФ менше 5\% фактично свідчить про відсутність ФНР, 5 - 60\% - про наявність фізіологічного ФНР, більше 60\% - про включення в процес “сплячих" нефронів. Якщо під час виконання навантажувальної проби ШКФ не підвищується, то ФНР немає. В такому разі можна стверджувати, що кількість нефронів у нирці зменшена, більше того - передбачити, що існуючі нефрони функціонують в тій чи іншій мірі в режимі гіперфункції, що у свою чергу $€$ важливим механізмом прогресування хвороби нирок.

Представлені межі ФНР визначені логікою фізіологічної компенсації нирок. У нормі одна нирка забезпечує приблизно 50 - 60 мл/хв/1,73 м² клубочкової фільтрації, дві нирки - 110 - 120 мл/хв/1,73 м². Видалення нирки призводить до компенсаторного підвищення ШКФ до 90 мл/ хв/1,73 м², тобто відбувається 50\% приріст. Єдина вроджена вікарно гіпертрофована нирка забезпечує 90 - 110 мл/ хв/1,73 м² клубочкової фільтрації, хоча невідомо, скільки в ній $є$ існуючих нефронів [11].

На нашу думку, основним фактором, який призвів до зниження ФНР після проведеного хірургічного лікування у пацієнтів 3-ї групи, є їх вік, коли відбулися інволютивні зміни в паренхімі нирок, що у свою чергу спричинило суттєве зменшення кількості функціонуючих нефронів (у нормі близько 2 млн. у двох нирках). Окрім того, слід звернути увагу на підвищення тиску в капсулі клубочків понад 2,6 кПа (20 мм рт. ст.) через сповільнення реабсорбції рідини в проксимальній частині канальців нефронів; обструкцію просвіту канальців циліндрами, некротичними масами; наявність перешкод виділенню сечі у сечових шляхах (некроз, згустки крові, пухлина); зміну стану клубочкового фільтра, кількості, площі та діаметра пор (у нормі до 5 нм); збільшення товщини клубочкової мембрани (у нормі 80-120 нм), зміни їі фізико- хімічних властивостей.

Порівняння розрахункової ШКФ та ФНР дає змогу зпрогнозувати перебіг хронічної хвороби нирок. Якщо ШКФ близько 60 мл/хв/1,73 м² (точка визначення хронічної хвороби нирок), ФНР у межах норми, можна стверджувати про наявність латентної фази захворювання. Іншими словами, $є$ пошкодження нефронів, але їх кількість не зменшена і компенсація відбувається за рахунок адаптивного збільшення канальцевого транспорту, такий стан можна вважати зворотним. Тобто застосування ренопротекції дає надію на відносно сприятливий перебіг патологічного процесу в нирках.

У подальшому, визначаючи ФНР, одночасно можна оцінити рівень альбумінурії. Якщо він підвищується під час проведення проби, можна зробити висновок про те, що в умовах волюмостимуляції, викликаної надходженням в організм $\mathrm{NaCl}$, у ниркову адаптивну відповідь включаються ті нефрони, які були “відключені” або у яких знижена ШКФ, оскільки вони є пошкодженими, і цей факт можна трактувати як виснаження ФНР [11,21].

\section{Висновки}

1. У пацієнтів з НКР віком від 25 до 43 років ФНР збережений. Через 1 міс після резекції нирки у хворих даної вікової групи не відбувається зниження ФНР.

2. У пацієнтів з НКР віком від 44 до 59 років ФНР також збережений. Через 1 міс після резекції нирки у хворих даної вікової групи відбувається зниження ФНР.

3. У пацієнтів з НКР віком від 60 до 74 років ФНР знижений. Через 1 міс після резекції нирки хворі даної вікової групи втрачають ФНР.

\section{Підтвердження}

Фінансування. Власним коштом.

Конфлікт інтересів. Автор заявляє про відсутнісь конфлікту інтересів.

\section{References}

1. Fedorenko ZP, Goulak LO, Michailovich YY, Ryjov AY, Sumkina OV. Cancer in Ukraine 2015 - 2016. Bulletin of National cancer registry of Ukraine. Kyiv; 2017. 86 p.

2. De Moor B, Vanwalleghem JF, Swennen Q, Stas KJ, Meijers BKI. Haemodynamic or metabolic stimulation tests to reveal the renal functional response: requiem or revival? Clin Kidney J. 2018;11(5):623-54. doi: 10.1093/ckj/sfy022.

3. Wildes TM, Maggiore RJ, Tew WP, Smith D, Sun CL, Cohen H, et al. Factors associated with falls in older adults with cancer: a validated model from the Cancer and Aging Research Group. Support Care Cancer. 2018;26(10):3563-3570. doi: 10.1007/s00520-018-4212-3. 
4. Sene AP, Hunt L, McMahon RF, Carroll RN. Renal carcinoma in patients undergoing nephrectomy: analysis of survival and prognostic factors. Br J Urol. 1992;70(2):125-34. PMID:1393433.

5. Wadowski PP, Hülsmann M, Schörgenhofer C, Lang IM, Wurm R, Gremmel T, et al. Sublingual functional capillary rarefaction in chronic heart failure. Eur J Clin Invest. 2018 Feb;48(2). doi: 10.1111/eci.12869.

6. Russo P, Goetzl M, Simmons R, Katz J, Motzer R, Reuter V. Partial nephrectomy: the rationale for expanding the indications. Ann Surg Oncol. 2002;9(7):680-7. PMID:12167583.

7. Lee CT, Katz J, Shi W, Thaler HT, Reuter VE, Russo P. Surgical management of renal tumors $4 \mathrm{~cm}$ or less in a contemporary cohort. J Urol. 2000;163(3):730-6. PMID:10687966.

8. Leibovich BC, Blute M, Cheville JC, Lohse CM, Weaver AL, Zincke H. Nephron sparing surgery for appropriately selected renal cell carcinoma between 4 and $7 \mathrm{~cm}$ results in outcome similar to radical nephrectomy. J Urol. 2004;171(3):1066-70. doi:10.1097/01.ju.0000113274.40885.db.

9. Ebbing J, Menzel F, Frumento P, Miller K, Ralla B, Fuller TF, et al. Outcome of kidney function after ischaemic and zero-ischaemic laparoscopic and open nephron-sparing surgery for renal cell cancer. BMC Nephrol. 2019;20(1):40. doi: 10.1186/s12882-019-1215-3.

10. Barreto EF, Rule AD, Murad MH, Kashani KB, Lieske JC, Erwin PJ, et al. Prediction of the Renal Elimination of Drugs With Cystatin C vs Creatinine: A Systematic Review. Mayo Clin Proc. 2019;94(3):500-514. doi: 10.1016/j.mayocp.2018.08.002.

11. Hozhenko AI, Kravchuk AV, Sirman VM, Nikitenko OP, Romaniv LV. Functional renal reserve: physiological value of renal reserve and substantion of the method of its determination. Kydney. 2015;(4):7-11. doi: 10.22141/2307-1257.0.4.14.2015.74890.

12. Amiel C, Blanchet F, Friedlander G, Nitenberg A. The functional renal reserve. Nephrologie. 1991;12(2):55-61 PMID:1944756.

13. Bosch JP, Saccaggi A, Lauer A, Ronco C, Belledonne M, Glabman S. Renal functional reserve in humans. Effect of protein intake on glomerular filtration rate. Am J Med. 1983;75(6):943-50. PMID:6650549.
14. Isharwal S, Ye W, Wang A, Abraham J, Zabell J, Dong W, et al. Impact of Comorbidities on Functional Recovery from Partial Nephrectomy. J Urol. 2018;199(6):1433-9. doi: 10.1016/j.juro.2017.12.004. doi:10.1016/j.juro.2017.12.004.

15. Rashidi Khazaee P, Bagerzadeh J, Niazkhani Z, Pirnejad H. Predicting the Function of Transplanted Kidney in Long-term Care Processes: Application of a Hybrid Model. J Biomed Inform. 2019;91:103116. doi: 10.1016/j.jbi.2019.103116.

16. Han QX, Zhang D, Zhao YL, Liu L, Li J, Zhang F, et al. Analysis of chronic kidney disease staging with different estimated glomerular filtration rateequations in Chinese centenarians. Chin Med J (Engl). 2019;132(5):512-518. doi: 10.1097/CM9.0000000000000079.

17. Van Londen M, Kasper N, Hessels NR, Messchendorp AL, Bakker SJL, Sanders JS, et al. Renal functional reserve capacity before and after living kidney donation. Am J Physiol Renal Physiol. 2018;315(6):F1550 F1554. doi: 10.1152/ajprenal.00064.2018.

18. Palsson R, Waikar SS. Renal Functional Reserve Revisited. Adv Chronic Kidney Dis. 2018 May;25(3):e1-e8. doi: 10.1053/j.ackd.2018.03.001.

19. Mistretta FA, Mazzone E, Knipper S, Karakiewicz PI. Benefit of nephron sparing surgery translates into lower cancer specific mortality in patients with localized renal cell carcinoma. Send to Ann Transl Med. 2018;6 (Suppl 2):S104. doi: 10.21037/atm.2018.11.37.

20. Verhagen PCMS, Boevé ER. The European Association of Urology Guideline on Renal Cell Carcinoma (RCC) is Not Concise in its Recommendation to Perform Partial Nephrectomy in T1b RCC. Eur Urol. 2019;76(1):132-133. doi: 10.1016/j.eururo.2019.01.020.

21. Papkevich II, Begun IV, Kazharskaya LG Functional renal reserve in children cured from nephroblastoma. Nephrology. 2002;6(4):66-9. doi. org/10.24884/1561-6274-2002-6-4-66-69.

Надійшла 14.06.19 